\title{
EL PANTANO DE RELLEU Y EL RIEGO DE LA HUERTA DE VILLAJOYOSA (1653-1879)
}

\author{
Pablo Giménez Font \\ Departamento de Análisis Geográfico Regional \\ Universidad de Alicante
}

\section{RESUMEN}

El presente trabajo trata de analizar los orígenes del proyecto y construcción de la presa de Relleu y su repercusión en los cambios espaciales de la huerta de Villajoyosa. Seguidora del modélico pantano de Tibi, el de Relleu introdujo una serie de mejoras técnicas destacables y su edificación — de iniciativa local con el beneplácito real — se acompañó de una fuerte polémica entre la población constructora y la vecina villa de Relleu, en cuyo término se levantó la pared. Se mencionan finalmente los intentos por evitar los problemas de colmatación, que terminarán por inutilizarla en la primera mitad del siglo $\mathrm{XX}$.

Palabras clave: Villajoyosa, pantano, Relleu, regadío.

\section{ABSTRACT:}

The current work is aimed at analysing the origins of the project and construction of the Relleu dam and it's repercussions in the spacial changes of the area known as la Huerta de Villajoyosa. Follower of Tibi's model dam, Relleu introduced a series of important technical improvements and it's construction —of local iniciative with the approval of the Monarch - was surrounded by strong controversy between the building population and the nearby Villa de Relleu, where the wall was erected. We also focus some problems of filling coming from the sediments found in the base, which will end up rendering it unusable in the first half of the XX century.

Key words: Villajoyosa, swamp, Relleu, irrigable.

El desafío climático que el Mediterráneo ha planteado al hombre de forma ancestral ha girado en torno al agua, genuino determinante económico y social de este espacio. Una relación esencialmente contradictoria, sobre la que se han fundido tanto los deseos de acapararla como los de eliminarla, en una lucha continua entre el hombre y el medio que ha dejado una extraordinaria impronta paisajística. 
Consecuencia de este hecho, los embalses se presentan como ejemplos de la primera necesidad, la de almacenar agua para combatir la siempre inoportuna sequía. Y de la misma forma acaparan, en ocasiones, la paradoja del Mediterráneo por el peligro que supone el estancamiento de la misma ${ }^{1}$.

Es el caso —-modélico — del pantano de Relleu que, además, merece una especial atención por sus características técnicas. Una obra patrimonial valenciana, que pertenece a ese conjunto de construcciones de escasa divulgación fuera de ámbitos científicos, escondida hasta para sus propios vecinos e infravalorada por la administración que, sin embargo, comienza a concienciarse del significado ${ }^{2}$ de lo que en definitiva es un formidable ejemplo de una ingeniería asombrosa, producto de la sociedad que, no sin problemas, consiguió levantarla.

\section{Relleu en el contexto general de los embalses levantinos de los siglos XVI-XVII}

En este sentido, el Sureste ibérico tiene el privilegio de ser considerado la cuna del modelo de presa moderna, como demuestran el total de ocho pantanos —incluyendo el de Alcora, en Castellón - construidos durante los siglos XVI y XVII.

Fruto, más que de una personalidad única, de un conjunto de ideas en estrecha relación con el desarrollo de la arquitectura e ingenierías renacentistas (López, 1994), este modelo tiene en la presa de Tibi —finalizada en 1594- el paradigma de los embalses que se construyeron a lo largo del siglo siguiente. Muestra inequívoca de los esfuerzos del hombre para vencer parcialmente la sempiterna sequía, estas presas fueron construidas para dar servicio de riego ${ }^{3} \mathrm{y}$, pese a no ser las únicas construidas en los siglos XVI-XVII ${ }^{4}$ en la Península Ibérica, destacaron por el tamaño y la introducción de novedades técnicas que inauguraron una nueva etapa respecto a las simples albercas medievales (López, 1996).

Efectivamente, la aportación revolucionaria de la planta curva junto con el escalonamiento del paramento de aguas abajo a finales del siglo XVI, permitió erigir unos embalses formidables para su tiempo. Se superó así la antigua presa de planta recta o de gravedad, donde la presión horizontal del agua embalsada se contrarrestaba por el empuje vertical de la masa del muro, de mayor grosor aguas abajo (López, 1994), y se entendió la aplicación al empuje hidrostático de las cualidades de resistencia del arco tumbado, con lo que la presión queda repartida entre la dirección horizontal de los arcos encajados en los estribos y las ménsulas verticales empotradas en el cimiento. (Navarro, 1994).

Pero si la presa de gravedad-arco, que tiene en Tibi y Almansa sus ejemplos prototípicos, supuso un avance revolucionario, no lo fue menos su sucesora, la presa-bóveda, de estilo más depurado y con muros de espesor uniforme. Algunos autores citan como presasbóvedas las de Almansa y Elche y otra italiana del siglo XVII, en Montalto. Según otros, sólo la de Relleu es verdaderamente de bóveda, aunque también puede considerarse prác-

1 Sobre esta cuestión vid. Fernand BRAUDEL (1976): El Mediterráneo y el mundo mediterráneo en la época de Felipe II. Ed. Fondo de Cultura Económica, Madrid; especialmente la primera parte del tomo I, dedicada a la influencia del medio ambiente.

2 En el Proyecto de Directrices para el Plan Hidrológico de la Cuenca del Júcar se propone su rehabilitación, junto a la de los pantanos de Elche y Tibi. Igualmente, la Consellería de Medio Ambiente ha incluido la laguna en el catálogo de Zonas Húmedas de la Comunidad Valenciana, recientemente aprobado.

3 Las presas destinadas a abastecimiento de agua para consumo urbano, en general, no aparecen hasta mediados del siglo XIX, momento en el que el rápido crecimiento urbano y el deterioro de las condiciones higiénicas de la ciudad así lo reclama (NAVARRO VERA, 1994).

4 Recordemos la de la Albufera del Castellar (Zafra), fechada en 1500, la de Granjilla (al SE de El Escorial), de 1560, la reconstrucción en 1572 de la de Ontígola (Aranjuez) o el inicio ese mismo año de la de Albuhera de San Jorge, cerca de Trujillo. 


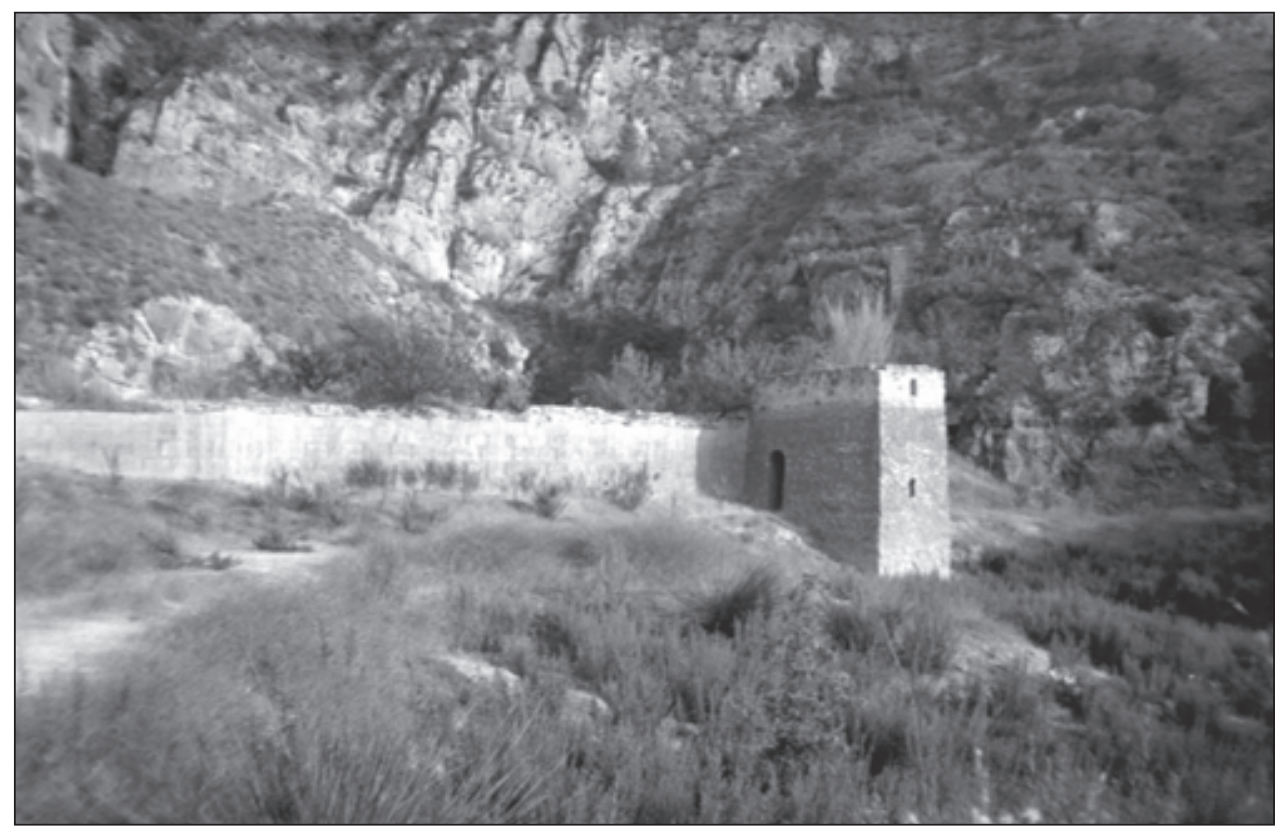

Fото 1. Detalle del estado actual de la presa vista desde aguas arriba. Sepultada bajo cerca de 30 metros de tarquines, tan solo sobresale el recrecimiento realizado en 1879.

ticamente así la de Elche (López, 1996). En ambas, el efecto arco interviene en su estabilidad y la esbeltez de la de Relleu, derivada de la relación entre altura y espesor, no fue superada hasta 1830 cuando el ingeniero Tholonet construyó la presa-arco de Zola (Navarro, 1994). A pesar de su importancia y de la visita a la región de científicos y técnicos de diversas nacionalidades, especialmente en el siglo XIX — cuando se proyectaban trabajos semejantes en diferentes países- los estudios más conocidos sobre riegos del Ochocientos, los del francés Aymard y el español Llauradó, omiten la de Relleu tras referirse a los embalses de Almansa, Tibi y Elche (López, 1971).

Como en el resto de las presas mencionadas, la de Relleu se sitúa en el cauce de un ríorambla como el Amadorio - junto a la confluencia del barranco de La Cova-, de módulo reducido — apenas alcanza $1 \mathrm{~m}^{3} / \mathrm{s}$. - y una fuerte irregularidad interanual, que puede pasar de las delirantes avenidas al estado de sequedad total la mayor parte del año. En la escasez reside el elevado valor del agua y el fin último de la construcción de la presa en una formidable angostura caliza que, a su vez, determina también su ubicación. Ciertamente, no es la mejor desde un punto de vista productivo - al contrario de lo que ocurre con la actual presa del Amadorio, que recoge igualmente las aguas del río Sella- pero el desarrollo técnico del XVII así lo hizo necesario. En efecto, esta posición permitió la construcción de muros de longitud mucho menor y más altura, pero se plantearon problemas de resistencia para evitar excesivo grosor. Esta cuestión, no obstante, se solucionó en parte con la gran innovación de la planta en arco, pero en Relleu se fue más allá y es ahí donde reside su originalidad: la estabilidad se consigue a través del equilibrio elástico del conjunto de la obra por el efecto de arco que transmite el empuje lateralmente a los apoyos, al igual que una bóveda. Por gravedad el peso de la obra es llevado a los cimientos, pero la distribución de la presión hidrostática entre el contrapeso vertical y la acción del arco 
depende de la rigidez del muro. Por ello son más adecuados en cerradas angostas y permiten construcciones de espesor reducido. El radio, de 60 metros, es constante en todo el muro, pero el ángulo es mucho menor abajo, donde la cerrada se estrecha hasta los escasos 2 metros y la presión del agua es mayor, por lo que se requiere un muro más grueso y de gran rigidez (López, 1971). A los 28 metros de altura, límite de la obra original, se abre hasta unos 40 metros, con lo cual bastaban 10 metros de espesor en el muro.

Igualmente original resulta en lo referido a la toma de agua que, como en Tibi, se realiza mediante un pozo que en la parte recrecida en 1879 adopta forma de torre adosada. A través de once aspilleras verticales a distintas alturas, el agua es conducida hasta su salida, una galería interior única que, al contrario que las restantes presas, en Relleu coincide con el desagüe de fondo - de 2 metros de anchura y unos 6 de alto - utilizado a su vez como mecanismo de limpia de los arrastres depositados en la base del vaso del embalse. Para maniobrar con seguridad la paleta de salida de agua de la toma, conformada por gruesos maderos, se utilizaba una cámara situada encima de la galería del desagüe de fondo a la que se accedía por un pasillo oblicuo a la presa (Navarro, 1994). Pero a pesar de estas innovaciones, la limpieza de los tarquines era dificultosa y no se hacía con la regularidad necesaria. El problema intrínseco de las aguas turbias, muy cargadas de lodo durante las crecidas, se convertiría a la postre en la causa de defunción del pantano de Relleu, que ha visto paulatinamente reducida su capacidad — de escasos $0,6 \mathrm{hm}^{3}$ - hasta quedar prácticamente anegado. A ello hay que añadir las filtraciones en la caliza nummulítica de la cerrada y parte del vaso, que la Confederación Hidrográfica del Júcar cifró, a embalse lleno, en 80 l/s; sin olvidar que se trata de una presa vertedero, ya que al carecer de aliviaderos de crecidas vierte sus excedentes de agua por coronación (Navarro, 1994), lo que puede ocasionar socavaduras en la parte inferior por el efecto cascada y desplomes en la superior, como así parece haber ocurrido en la parte alta de la presa, donde el desprendimiento de algunos sillares del revestimiento ha hecho aflorar la mampostería del núcleo.

\section{Un proyecto que nació en Aranjuez}

Si bien se desconoce la fecha exacta del inicio de su construcción, la gestación de la presa de Relleu comenzó ya en tiempos de Felipe III, aunque únicamente se pudo entonces «hacer visura del sitio sin procederse por entonces a otra diligencia, antes bien ocurrido que fue el fallecimiento de dicho monarca, hubo de calmar el asunto y aun extraviarse sus documentos $»^{5}$. En 1630, se retomó de nuevo la empresa cuando el síndico de Villajoyosa acudió a Felipe IV exponiendo la decadencia de la villa por falta de cosechas, a causa de la escasez de aguas para riego. La principal alegación se fundamentaba en el preocupante descenso demográfico, por lo que se hacia necesario la construcción de un pantano «a legua y media en el término de Relleu» ${ }^{6}$, mediante el cual asegurar las cosechas e incrementar así el número de habitantes. Para reforzar el proyecto, se resaltaba la importancia estratégica de la población costera, situada entre las plazas fuertes de Alicante y Denia y que servía tanto para refugio de las embarcaciones acosadas por los corsarios como lugar de acogida de la población dispersa en los campos cuando se producían incursiones berberiscas en el litoral. El embalse de Tibi —modélico no sólo en el aspecto técnico- era tomado como ejemplo a la hora de arbitrar las medidas para construir la presa en un término municipal ajeno como era el de Relleu, que sería recompensado ante cualquier daño, perjuicio o menoscabo que causase la obra.

5 Archivo Histórico Nacional (A.H.N.) Consejos. Leg. 22.605: Solicitud de Santiago Gómez Delgado para que se deniegue la aprobación del documento de Concordia de 1777.

6 A.H.N. Consejos. Leg. 22.605. Solicitud de Santiago Gómez... 
La solicitud fue remitida el 10 de octubre de ese mismo año al Marqués de los Vélez, Virrey de Valencia que, junto a la Real Audiencia, debía informar al Rey sobre la petición. El Conde de Fuentes, Señor de Relleu, y Luis de Cardona, Administrador de la Encomienda de Orcheta, de la Orden de Santiago, manifestaron su oposición a la solicitud de Villajoyosa, pero sus alegaciones fueron descartadas por falta de fundamento. El 18 de julio de 1631, la Audiencia envió a un arquitecto para que reconociera el lugar y tuviera en cuenta las pretensiones de las partes involucradas, llegando sus conclusiones a manos del Virrey cinco meses después. Enterado de todo ello, el 9 de febrero del año siguiente, el Rey ordenó a la Audiencia un nuevo reconocimiento por parte de dos peritos «prácticos en semejantes fábricas, y a costa de las arcas vileras, enterándose del beneficio que podría seguirse de su construcción así a la Real Hacienda, como a la misma villa; calculando la extensión del terreno regable con sus aguas, el tiempo y coste de su fábrica y el interés que de ella se podía seguir al dueño de la villa de Relleu y al Comendador de la de Orcheta, como también si sería o no perjudicial a otro tercero» ${ }^{7}$. Las conclusiones de los dos técnicos, que habían sido nombrados por el oidor de la Audiencia Onofre Bertomeu Ginant, junto con una copia «de lo concedido para la construcción del pantano de Alican$t e^{8} »$ fueron remitidas al Virrey, y por éste al Rey, el 22 de diciembre de 1632, al mismo tiempo en que el monarca recibía una nueva representación de Villajoyosa.

Los aspectos referidos a la pérdida de tierras por la construcción del pantano y el empeoramiento de la salubridad, sin duda los más escabrosos del asunto y sobre los que Relleu basaría durante décadas sus alegaciones, no debieron quedar demasiado claros en el informe anterior, por lo que en marzo de 1633 el monarca, de nuevo, ordenaría al Virrey «verificase si los dueños de los pueblos que habían hecho oposición, tenían con efecto, interés en las tierras que había de inundar el pantano y si éste sería o no perjudicial a la salud de las gentes de aquel País, cuyo punto se examinase por medio de visura de Médicos y otras personas inteligentes, volviendo a informar sobre todo con acuerdo de la misma Audiencia» ${ }^{9}$. Dos doctores de la Facultad de Medicina de la Universidad de Valencia se encargaron de elaborar el correspondiente dictamen, cuyo contenido desconocemos. Lo cierto es que, ante la inminencia de la aprobación de la obra, Orcheta se retiró del pleito el 12 de agosto de ese mismo año, pero Relleu todavía interpuso varias alegaciones a los capítulos propuestos por Villajoyosa que fueron denegadas. Finalmente Felipe IV otorgó el Real Privilegio el 8 de mayo de 1653 en Aranjuez:

«para que procediese la Villa de Villajoyosa a su obra y erección, del modo, altura, fórmula y estado que les pareciera conveniente, sin que en adelante ni en tiempo alguno, sirviese de reparo, obstáculo o impedimento cualquier defecto y perjuicio de tercero» ${ }^{10}$.

Mediante este documento se concedieron a Villajoyosa capítulos que hicieron posible la financiación de la obra: al igual que Alicante con el pantano de Tibi, la población costera debía administrar en exclusividad las aguas de riego y aportar el capital necesario para la adquisición de terrenos y realización de obras, compensándola posteriormente con el tercio del Diezmo perteneciente a la Real Hacienda por las nuevas cosechas obtenidas. El reparto de las aguas era competencia únicamente de los oficiales de Villajoyosa, y los regantes,

7 A.H.N. Consejos. Leg. 22.605: Solicitud de Santiago Gómez...

8 A.H.N. Consejos. Leg. 22.605: Solicitud de Santiago Gómez...

9 A.H.N. Consejos. Leg. 22.605: Solicitud de Santiago Gómez...

10 A.H.N. Consejos. Leg. 22.605: Representación del procurador Santiago Gómez Delgado ante el Consejo de Castilla, 1 de junio de 1772. 
sólo vecinos de esta última, obtendrían el agua en proporción a la tierra que poseyeran. El Privilegio también especificaba el pago por todos los vecinos sin excepción de cualesquiera de las actuaciones necesarias para la conservación o fortalecimiento de la obra, así como la protección de los tres molinos y tres hornos situados en la huerta vilera. Ante el previsible aumento de población que supondría la obra, se autorizaba la construcción de nuevos molinos y hornos, dados en enfiteusis y con un censo anual de 10 sueldos pagando quindenios. Finalmente, se excluía de los posibles beneficios del pantano a las poblaciones de Orcheta y Relleu, aduciendo que la construcción de la pared se realizaba en zona estéril y montañosa de ambos términos.

La respuesta del Conde de Fuentes no se hizo esperar, exponiendo, en una serie de puntos, su oposición a la construcción de la pared en el término de su baronía. Pese a ello, no dejaba de reclamar ciertos beneficios derivados de la implantación de la presa. Así, por ejemplo, conminaba a Villajoyosa a pagar justiprecio por las tierras necesarias para su construcción, bien a los titulares del Señorío, bien a sus vecinos, salvo que se concediera la pesca y la caza que allí se pudiera obtener. Efectivamente, reclamaban la exclusividad de las actividades cinegéticas que pudiera generar el pantano, bajo multa de 25 libras y pérdida de instrumental de caza y pesca a quien trasgrediera esta norma. De igual manera la leña y madera que se necesitara para construir el pantano, siempre que Villajoyosa no tuviera privilegio ni facultad para cortar leña en términos circunvecinos, se pagaría a sus propietarios.

El titular del Señorío reclamaba también el derecho de poder construir molinos en cualquier lugar del término de Relleu y Villajoyosa, sin que ésta pudiera impedir su edificación, una vez pagado el justiprecio de la tierra a sus propietarios. A esto respondió en desacuerdo Villajoyosa, que adujo la libertad de Relleu para construir un número indeterminado de molinos pero únicamente en su término y siempre bajo el requisito de permitir el paso de las aguas al vaso del pantano.

El aspecto referido a la salubridad de las aguas, que será ampliamente tratado en el pleito - ya en el siglo XVIII- entre ambas poblaciones por el recrecimiento de la presa, aparece de forma extensa en el Real Privilegio. Ante el temor de que el agua se corrompiera por escasa y largo tiempo inmovilizada, el Barón reclamaba su derecho a vaciar el pantano - corriendo los gastos de la operación a cargo de Villajoyosa - y poseer la llave de una paletilla que, a 8 palmos del suelo de la presa, habrían de instalar los vileros para tal fin. Para determinar si el agua era peligrosa para la salud, el Señor de Relleu planteaba el nombramiento de dos peritos, uno por cada población, y un tercero por parte del Gobernador de Valencia en caso de discordia.

El grueso de las alegaciones al Real Privilegio giró en torno a la condición de señorío de la villa de Relleu. Tras recordar la Jurisdicción Baronal ${ }^{11}$ a la que seguía sometido el territorio donde debía levantarse la presa, reclamaban, como titulares del dominio directo, el pago de 20 sueldos con fadiga y luismo. Obviamente, a esto último se opuso Villajoyosa, aduciendo que no pagaría censo alguno por tierras ya vendidas por el titular del Señorío, sin dejar de señalar que se trataba de un terreno inculto sin posibilidad alguna de poner en valor:

11 Por la cual si algún oficial de Villajoyosa cometiese delito en el término de Relleu, correspondía el castigo a los Señores de Relleu. 
«son peñas vivas en que los Señores de Relleu no tuvieron ni jamás pueden tener utilidad alguna, ni aquel puesto es vendible ni a propósito para otro efecto alguno» $^{12}$

Tampoco se concedió el último punto de las aspiraciones baronales: en caso de abandono por Villajoyosa del pantano, nada de lo construido revertiría a los Señores de Relleu.

A pesar del decidido apoyo real, la multitud de disyuntivas y conflictos entre los municipios afectados, los intereses contrapuestos y, ante todo, la falta de capital, supuso el lógico retraso en la construcción de la obra y evitó también la plena finalización de la misma, como indicaba el abogado Jaime Aragonés en el seco verano de 1747: "por falta de medios no se levantó más, porque cuando se fabricó la obra [...] tomó la Villa diferentes cambios, mayormente hallándose entonces, según se ha dicho, la Villa y su Común con algunas calamidades, que por muchos años padecieron, ya dividida en bandos, pocas cosechas, e invasiones de los piratas argelinos» ${ }^{13}$. Se desconoce, no obstante, la fecha del inicio de su construcción y la de su conclusión, que algunos autores sitúan en 1689 (Gómez, Juan-Aracil, 1952). Esté acertada o no la datación ${ }^{14}$, sí que podemos asegurar que en la primera década del siglo siguiente la presa, aunque no concluida totalmente ${ }^{15}$, ya retenía las aguas del Amadorio y posiblemente también gran cantidad de limos.

\subsection{Las labores de mantenimiento}

Efectivamente, un deficiente mecanismo de limpia junto con las características intrínsecas de los aportes torrenciales, condicionaban unas labores de mantenimiento, reparación y limpia demasiado constantes, tanto, que el problema del enrunado del vaso del pantano terminó por vencer paulatinamente la constancia de los vileros.

En las Actas Capitulares del Ayuntamiento de Villajoyosa hay continuas referencias a este tipo de tareas, realizadas con más asiduidad en un principio, para ir disminuyendo con el paso del tiempo. Las hay que resultan significativas y en algunas ya se señalan, como en un acta del Ayuntamiento de septiembre de 1717, los problemas derivados de la acumulación de lodos: «el Pantano [...] está muy lleno de cieno de las avenidas, que no coge la agua bastante, por lo que es de sentir se corten los tablones, se salga el cieno y se limpie dicho pantano con la primera avenida que Dios envíe por que de dilatarlo será llenarse de más de las avenidas, y endurecerse más el cieno, que después de limpiarse le ha de costar a la Villa muchos Reales, a más de la pérdida del agua» ${ }^{16}$.

La tarea de limpia consistía en acceder a la galería de desagüe y serrar los tablones de la compuerta facilitando así la salida del fango para, una vez finalizada la operación, obturar el conducto con nuevos tablones, ramaje y tierra ${ }^{17}$. La operación, que "por el peso

12 A.H.N. Consejos. Leg. 22.605: Solicitud de Jaime Lorca y Jaime Urios, de copia testimoniada del Real Privilegio que hacia 1630 concedió a Villajoyosa Felipe IV para edificar el pantano. 19 de mayo de 1772.

13 Archivo Municipal de Villajoyosa (A.M.V.), Libro de Deliberaciones, Acta del 7 de junio de 1749.

14 Existe otra fecha, 1628, que ofrece el Ministerio de Obras Públicas en su Plan General de Obras Públicas (1940) que, obviamente resulta imposible. El Cronista Oficial de Villajoyosa, José Payá Nicolau afirma que aparecen referencias del pantano en los documentos municipales de 1710 en adelante.

15 Calculamos que se elevaría hasta los 24'55 metros.

16 A.M.V., Libro de Deliberaciones, Acta del 16 de Septiembre de 1717.

17 De igual forma aparece descrita la operación en los Art. 28 y 29 del Reglamento de las aguas de Villajoyosa de 1834 y el Art. 23 de las Ordenanzas para el régimen y gobierno de la Comunidad de Regantes y reglamentos para el Sindicato y el Jurado de Riegos del Mayor de las huertas de Villajoyosa, redactadas en 1889 y aprobadas en 1907, aunque sin precisar la frecuencia de la operación. 
del cieno y el agua como por estar el cieno blando» resultaba harto peligrosa ${ }^{18}$ dada la posibilidad de que «se reviente aquella inmundicia y padezcan los hombres que trabajaren en dicho puesto» ${ }^{19}$, fue encomendada, en septiembre de 1717, al pantanero Francisco Ruiz, que días después, el 12 de octubre, planteaba serios problemas para efectuar la limpieza:

«si no se cava y se van sacando las piedras, atocha y algún poco de cieno, que hace firme la misma boca del pantanico, será imposible que venga aquel cieno y se limpie el pantano, que respecto de tener el pantano limpio es de toda conveniencia a la Villa para el riego de su huerta» ${ }^{20}$

Las obras de mantenimiento de la pared también eran habituales, generalmente en paralelo a los daños que podían causar las avenidas del Amadorio en una construcción que, como ya hemos señalado, vierte sus excedentes de agua por coronación. Pero veían dificultada igualmente su ejecución por aspectos tan diversos como la disponibilidad de capital o los derivados de las condiciones climáticas. Ejemplo de esto último lo encontramos en 1733, cuando el cabildo de Villajoyosa se vio obligado a posponer en tres ocasiones las obras de reparación de la pared del pantano: en primer lugar, porque aquel verano fue tan seco que no se disponía de «agua para poder amasar la cal ni aun para beber en el discurso de tres meses», la llegada del invierno volvió a dificultar las obras, ya que «aquel paraje es muy frío y la obra no se podrá empezar y que era de sentir dicho maestro [albañil] se prorrogase para el mes de abril del año venidero»; pero en mayo del siguiente año, llegaba al ayuntamiento una solicitud de más fondos «para poder concluir las piedras que faltan para la citada obra [...] por haberse llevado la avenida del agua parte de la cal y mampostería» ${ }^{21}$.

Convertido, junto a la font de l'Arc, en elemento clave para del desarrollo de la huerta vilera, el «pantanico», como es denominado en los documentos hasta 1776, comenzó a perder su diminutivo en el momento en que se fraguó el definitivo proyecto que finalizaría la obra iniciada en Aranjuez 119 años antes. Habían sido varios los intentos de solicitar al Rey el permiso pertinente para elevar la pared; en 1749 se otorgó poderes al Doctor Nogueroles, residente en la Corte, para conseguir copia del Real Privilegio de 1653 e iniciar con ello las gestiones pertinentes para la consecución del real permiso. Tres años después se elevó la solicitud a la Real Audiencia de Valencia a través del abogado Don Jaime Aragonés, pero ninguno de los intentos prosperó. Finalmente, el 19 de mayo de 1772, el Consejo de Castilla recibió la solicitud de un representante del Común y regantes de Villajoyosa, mediante la cual requería el imprescindible permiso para aumentar la pared del pantano. Se abría, una vez más, un contencioso entre las dos poblaciones en torno a la presencia de la presa y, de nuevo, la población costera reforzaba su petición con una serie de datos que pretendían demostrar los beneficios económicos y sociales de la construcción de la obra, "que por cada palmo que se aumentará la pared, se seguirá mucho aumento a dichas huertas por la mucho agua más que recogerá, pues en la poca obra que hay

18 La sabiduría popular denominaba a esta operación «lo de l'home mort», en clara referencia al fallecimiento de algún obrero en las labores de desembozo. CAVANILLES, (1797) en sus Observaciones sobre la Historia Natural, Geografía, Agricultura, Población y Frutos del Reyno de Valencia. Imprenta Real de Madrid. Ed. facsímil, Valencia, 1987, tomo II, pág. 86, se refiere a un caso similar para el pantano de Tibi, con la muerte - arrastrados por el lodo- del escribano de Alicante y un comisionado que verificaban las labores de limpieza del embalse.

19 A.M.V., Libro de Deliberaciones, Acta del 16 de Septiembre de 1717.

20 A.M.V., Libro de Deliberaciones, Acta del 12 de Octubre de 1717.

21 A.M.V., Libro de Deliberaciones, Acta del 3 de Septiembre de 1733. 
construida se ve, y ha visto claramente los colmados beneficios que dichos regantes han experimentado» ${ }^{22}$.

\section{El pantano y la huerta vilera: una aproximación}

Jaime Lorca y Orts, Síndico, y Jaime Urios, Procurador General y Personero del Común de Villajoyosa otorgaron poderes a Santiago Gómez Delgado, Francisco Antonio de Esategui y Narciso Francisco Blázquez, Procuradores de los Reales Consejos, para solicitar al de Castilla el aumento de la pared. Para ello, Lorca y Urios primero, realizaron una presentación de los beneficios que el riego reportó a la población, cuyo aumento trataron de demostrar mediante los libros del Equivalente, donde se anotaban anualmente los contribuyentes. Para el mismo fin, ambos solicitaron al Escribano de Marina el Libro de Matrícula o de asiento del número de vecinos reclamados para el servicio de la Real Armada. Todo ello tenía la finalidad de demostrar el fuerte aumento demográfico de una población que había pasado de los aproximadamente 1.290 habitantes en 1646 a los 4.221 de 1767 (Quereda, 1978), como consecuencia —en opinión de los síndicos- de los beneficios que el riego había reportado a la villa y al consiguiente incremento de las cosechas:

«los campos reducidos a una hermosa y dilatada huerta, donde se cogen copiosos frutos de seda, trigo, panizo, almendra, algarrobos y todo género de frutales, y poblada de muchos y hermosos edificios $»^{23}$

En paralelo a ello la villa, que se había fortificado, vio florecer un emergente comercio marítimo ${ }^{24}$ que ocupaba a 370 marineros:

«con muchos bastimentos propios de los vecinos que trafican por todos los puertos de estos y extraños Reinos, sacando los frutos de la tierra y trayendo otros de que se carece en ella» ${ }^{25}$

La realidad, como es de suponer, no debía ser tan idílica, aproximándose más bien, como en la huerta de Alicante, a las capacidades propias de un secano mejorado cuyos rendimientos bastarían para cubrir las necesidades de los labradores; sin olvidar tampoco que determinados cultivos producirían excedentes comercializables (Alberola, 1994). Efectivamente, el panorama general de la agricultura de los siglos XVI-XVII, básicamente centrada en el autoconsumo en la mayoría del territorio valenciano y con algunas excepciones localizadas de agricultura comercial, comenzó a virar tanto en términos cualitativos como cuantitativos al iniciarse el Setecientos y una vez superado el trauma colectivo que supuso la Guerra de Sucesión.

En un testimonio dado en Valencia en el año $1607^{26}$ por Melchor Llinares, vecino de Villajoyosa, quedan plasmadas las esperanzas de ampliar la zona regada una vez construi-

22 A.M.V., Libro de Deliberaciones, Acta del 7 de junio de 1749.

23 A.H.N. Consejos. Leg. 22.605: Representación del procurador Santiago Gómez...

24 Cavanilles, años después, destacaría la poderosa industria pesquera y comercial-marítima de Villajoyosa y las actividades relacionadas con ella, como son las almadrabas y las manufacturas de esparto. CAVANILLES, A. J. (1797): Observaciones..., tomo II, p. 244.

25 A.H.N. Consejos. Leg. 22.605: Representación del procurador Santiago Gómez...

26 En ORTS I BOCH, P.M. (1999): Introducció a la història de La Vila Joiosa i el Notari Andreu Mayor. Reedición del Ayuntamiento de la Vila Joiosa, pág. 133. 
da la presa: «...que la horta de la dita vila que huy és y la que se pot regar is rega seran doscentes quaranta jornades ${ }^{27}$ de terra y la ques pot ajuntar y fer horta, que huy és secá fent-se lo pantano seran altres doscentes quaranta jornades de terra poch més o menys».

Este crecimiento general a lo largo de la centuria, puede explicarse como el resultado de un numeroso y variado conjunto de iniciativas en las que, no obstante, no encontramos huellas de innovaciones capaces de determinar un salto en la producción agrícola (Artola, 1978). Efectivamente, el desarrollo agrario del Setecientos se basó, esencialmente, en la superposición de una doble acción sobre el medio natural conducente a incrementar la superficie cultivable e intensificar la producción a través de la extensión del regadío y la introducción de nuevos cultivos (Alberola, 1999), signos de un notable dinamismo que coexistían y formaban parte a la vez del sistema agrario tradicional (Ruiz, 1989).

La lógica ampliación de la superficie regada acarreó una serie de alteraciones relacionadas con la organización del riego y la adscripción del agua a la tierra. Efectivamente, la desproporción entre los caudales del Amadorio y la creciente superficie de tierras en regadío, junto con la distribución del agua mediante un estricto cómputo horario, se produjo en paralelo a un fenómeno - extendido a lo largo de los regadíos deficitarios del sureste peninsular - consistente en la transformación del agua en propiedad independiente de la tierra (Gil, 1993) dado su creciente valor $^{28}$. En este contexto de acaparamiento y expansión agrícola, comenzaron a proliferar actuaciones de pequeña entidad que complementaban la importante obra del pantano, en una huerta en la que se podían diferenciar dos grandes sectores: los riegos d'amunt y los d'avall, donde podemos incluir la pequeña área de els horts ${ }^{29}$, situada en el NE de la población.

Las aguas del Sella, tan importantes como las del propio pantano por los aportes de la imprevisible pero prolífica font de l'Arc, quedaban divididas en el término de Orcheta por un polémico partidor ${ }^{30}$ que enviaba a la huerta vilera un tercio del caudal existente. En la confluencia de este río y el Amadorio, se hallaba otro azud que regulaba el agua del rec d'amunt, proyectándose una ampliación a mediados del Setecientos ${ }^{31}$ que no fue realizada hasta 1848, momento en el que se pasó a denominar l'assut gran, con una capacidad de retención de 2.000 palmos cúbicos ${ }^{32}$. Hasta ese instante, la función primordial en el reparto de las aguas la cumplía el llamado assut d'avall, sito en la partida de Alcocons y construido en $1719^{33}$, a través del cual se adjudicaban dos terceras partes para el riego d'amunt correspondiendo el resto al d'avall.

27 Equivale a 115'24 ha. (un jornal se corresponde con 0,4802 ha.)

28 Les Puntes, un pequeño sector situado en la margen derecha de la desembocadura del Amadorio se mantenía como el único vestigio de la extinguida unión entre ambos dominios.

29 Aparece como tal a partir de las Ordenanzas redactadas en 1889.

30 Son continuas las referencias a enfrentamientos entre ambas poblaciones por el partidor, ya que en ocasiones no llegaba el agua a la huerta vilera o lo hacía muy menguada. Los destrozos de esta obra y hurtos de agua fueron muy comunes haciendo necesaria la intervención de la Real Audiencia de Valencia en varias ocasiones. En 1804 el Real Patrimonio reformó el partidor para evitar manipulaciones hasta que, en 1836, fue finalmente destruido por los vecinos de Orcheta, población que tuvo que correr con los gastos de su reposición. Agradezco la valiosa información que, en este sentido, me ha sido prestada por los hermanos Payá Nicolau, del Archivo y Biblioteca Municipal de Villajoyosa

31 Hemos encontrado una referencia a la necesidad de perfeccionarlo para evitar manipulaciones en el reparto del agua en el año 1726, sin que conozcamos si finalmente se llevó a cabo tal actuación. De igual forma, un manuscrito anónimo sitúa en 1748 el origen del proyecto de reforma realizado finalmente en el siglo XIX, sin que hayamos conseguido demostrar su veracidad.

32 Vid. Madoz (1850): Diccionario Geográfico-Estadístico-Histórico de Alicante, Castellón y Valencia. Edición a cargo de la Institució «Alfons el Magnànim». Diputació Provincial de Valencia, 1982. II tomos.

33 A.M.V. Libro de deliberaciones, Acta del 27 de mayo de 1719. 


\section{APROXIMACIÓN AL RIEGO TRADICIONAL DE LA HUERTA DE VILLAJOYOSA}
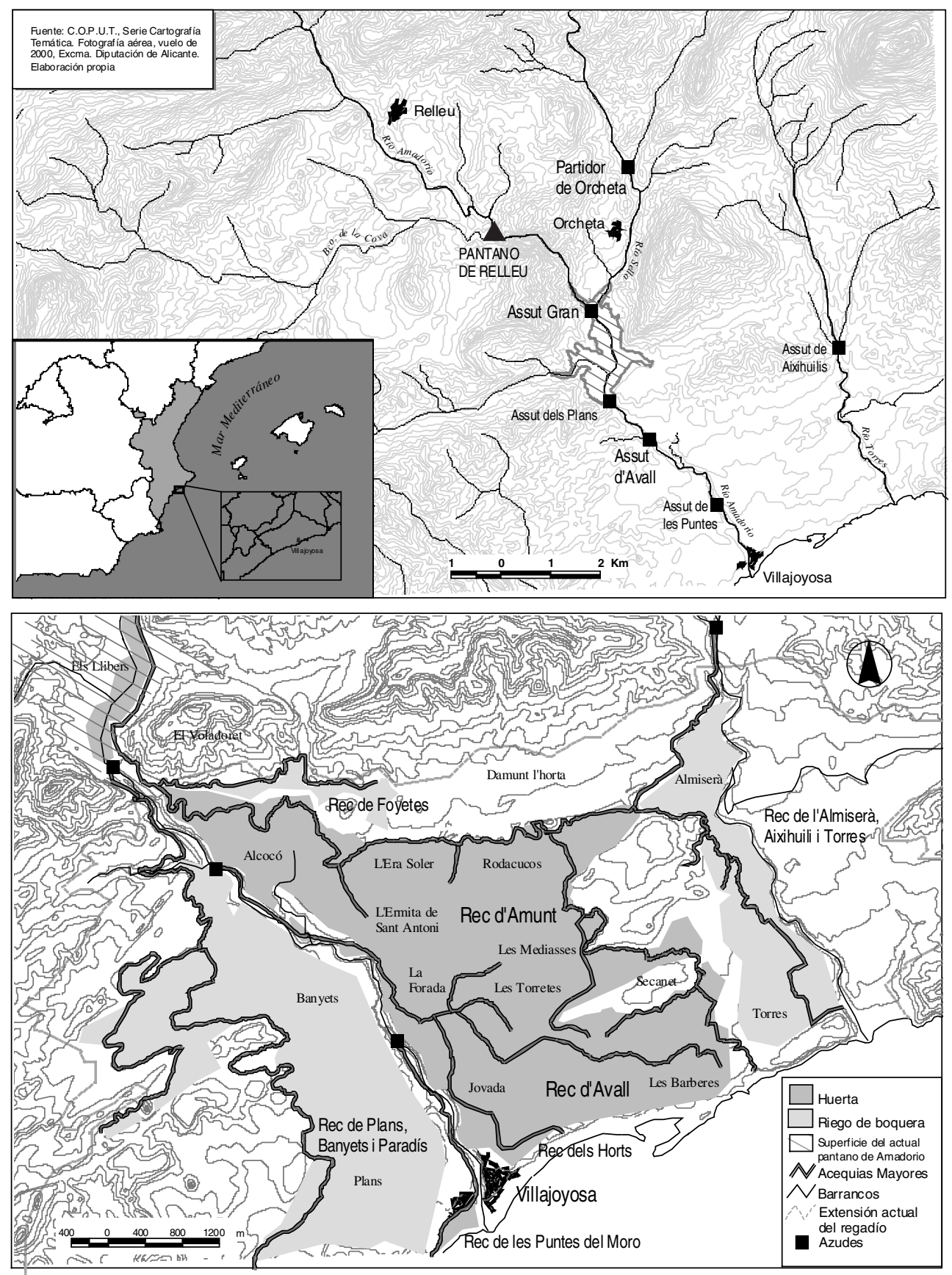
Alrededor de ambos elementos se fue configurando el crecimiento de una huerta en expansión, en la que encontramos excelentes ejemplos del dinamismo que en este sentido se originó en la población y, por extensión, en el Reino de Valencia. Tal es el caso de la puesta en regadío - eventual, mediante la construcción de un azud ${ }^{34}$ - en 1796, de una importante superficie de la margen derecha del Amadorio $^{35}$, una empresa encabezada por el sacristán Joaquín Vilana, hombre emprendedor que, en 1804, adquiriría la font de l'Arc para su sondeo e infructuosa explotación.

En definitiva, en este contexto de progresiva extensión y mejora del regadío, se fue configurando, en letra de Cavanilles, «un jardín precioso de dilatadas huertas, con multitud de casas que blanquean entre los varios verdes de moreras, maíces y otras producciones $[\ldots] \gg^{36}$.

Efectivamente, el botánico ilustrado citaba más de 600 casas repartidas por la huerta, y poco antes, en 1779, Tomás López cifró en 700 las familias que la habitaban en verano:

«que todos tienen en ella posesiones y casas de habitación; pero en el invierno se retiran a sus casas de la villa, menos los que mantienen posesiones grandes, que dejan sus pingües habitaciones a sus respectivos medieros y herreteros y otros, aunque más pobres, que se quedan para más utilidad de sus haciendas» ${ }^{37}$.

No es necesario encarecer que Villajoyosa, contando con rentables actividades aparte de la agricultura, encontraba en su huerta una de sus principales fuentes de riqueza y cohesión social alrededor del riego, un aspecto fundamental para comprender la construcción de obras como la del pantano, de iniciativa y financiación local en origen. Pese a todo, y como ya señaló López Gómez (1996), la construcción de embalses no permitió alcanzar la intensidad de cultivos deseada, que era la de los huertos de ríos caudalosos como el Júcar o el Túria. Ciertamente, se continuó en gran medida con las cosechas tradicionales pero con la importante novedad de conseguir incrementarlas, aliviar los brutales estiajes y terminar con parte de la aleatoriedad que las caracterizaba, sin olvidar tampoco que el nuevo riego permitió aumentar cultivos exigentes en agua como los frutales, alfalfa, moreras y hortalizas e introducir nuevos procedentes de América, como el maíz.

\section{Un duro enfrentamiento con Relleu}

Los importantes beneficios que obtenía la villa con el aumento de la disponibilidad hídrica junto con, tal vez, la necesidad de superar los constantes problemas de colmatación del vaso, descartaban toda reticencia en contra del recrecimiento de la pared. Finalmente, Villajoyosa decidió implicarse en un costoso pleito con la población vecina de Relleu, siempre recelosa de la presencia de la pared en su término.

Como era de esperar, los problemas comenzaron de inmediato, con la colaboración de algunos vecinos de la baronía al progresivo enrunado del vaso del pantano. En efecto, eran

34 Situado en el emplazamiento de la actual presa del Amadorio. En 1907, se construyó un nuevo azud - conocido como assut dels Plans - con el mismo fin, pero desconocemos si se erigió sobre el anterior. En esa misma actuación se restauró un acueducto para la conducción de sus aguas que, con seguridad, tuvo su origen en el proyecto de Vilana. Agradezco a Gaspar Lloret, de la Comunidad de Regantes, sus puntualizaciones sobre la distribución tradicional del riego en la huerta vilera.

35 Partidas de Plans, Banyets, Piletes y Parais.

36 CAVANILLES, A. J. (1797): Observaciones... pág. 244. Tomo II.

37 CASTAÑEDA Y ALCOVER, V. (1919): «Relaciones Geográficas, Topográficas e Históricas del Reino de Valencia de Tomás López. S (XVIII)». Ed. facsímil de la Generalitat Valenciana, 1998. Tomo I, pág. 140. 
acusados por el representante de Villajoyosa de intentar colmatar el embalse arrojando «muchas y gruesas peñas». Suponía un antecedente más de la animadversión que, desde sus orígenes, creaba la obra en una población local que ante la amenaza del recrecimiento, aseguraba «que han de dar barreno al Pantano para distraer las aguas, y que han de practicar en fin cuantas ideas les sugiera su malicia» ${ }^{38}$.

La población propietaria de la presa alegaba, igualmente, que la condición de Señorío de Relleu le restaba autoridad para perturbar el progreso de una villa de Realengo como era Villajoyosa y de la que se había visto favorecido con la defensa costera contra las razzias corsarias. Por todo ello conminaba al Conde de Puñonrostro, titular ahora del Señorío, y a su Ayuntamiento a que expusieran los fundamentos de derecho que les asistían para impedir las obras en el Pantano.

Un mes después, el 6 de junio de 1772, el Relator del pleito, D. Gil Cortés, propuso al Consejo que aceptará la petición de Villajoyosa, al no encontrar razones de peso por las que los vecinos de Relleu se opusieran a las obras. Se buscaba de igual forma evitar litigio alguno que dilatara aún más el proceso burocrático, como ya ocurrió con el Real Privilegio de 1653, y retrasara la ejecución de unas obras de extrema importancia para Villajoyosa. Circunstancia ésta que parece ser no se logró, como se desprende de la solicitud de Gómez Delgado para que el pleito se trasladara a la Sala $2^{\mathrm{a}}$ del Consejo, «por estar la primera saturada de trabajo, y ser perjudicial el retraso a los intereses de Villajoyosa ${ }^{39}$. El 10 de enero de 1774, casi dos años después, el expediente se trasladó a la Sala $2^{\mathrm{a}}$ de Gobierno del Consejo y cinco días después este organismo conminaba al Juez de Letras de Realengo más cercano, en este caso el Corregidor de Jijona, a emitir un bando en Relleu por el cual se reconocía a Villajoyosa el derecho a levantar la pared de la presa, bajo multa de 50 libras para todos aquellos que intentaran impedir la obra o arrojaran piedras u otros materiales al pantano. A su vez, se permitía la construcción de una casa para los guardas que velarían por las obras ya que, como escribía Gómez Delgado en la solicitud, «todo se debe temer de un pueblo resentido y encaprichado sin visos de justicia» ${ }^{40}$.

Sin embargo, la postura de Relleu — derivada también de un lógico sociocentrismoera comprensible en una época en la que el paludismo, con la llegada de los calores estivales, causaba estragos en la población. La virulencia de esta enfermedad endémica, relacionada con la presencia de aguas estancadas, sufrió un incremento a partir de los años cincuenta del siglo XVIII. En paralelo, se produjo un aumento en la preocupación de los poderes públicos valencianos (Alberola y Bernabé, 1999) y una agria polémica sobre tan escabroso tema, en el que confluían enfrentados aspectos económicos y de salubridad. En el caso de Relleu, al que la presa no aportaba ningún beneficio económico, la aprensión ante la presencia de agua embalsada y relativamente cercana a la población estaba razonablemente asegurada. Incluso Cavanilles, del que es bien conocida su lucha contra las actividades que requirieran un embalse considerable de agua - léase arrozales o pantanos- no pasó por alto esta cuestión en su discurrir por Villajoyosa: "La salud de los hombres ha de ser siempre la ley principal: cuanto le daña debe excusarse. Ni es lícito aumentar o mejorar los frutos en perjuicio de tercero». Contrario al recrecimiento de la pared, no dejó de plantear alternativas a esta actuación mediante la construcción de una red

38 A.H.N. Consejos. Leg. 22.605: Solicitud de Gómez Delgado para que la representación de 1 de junio de 1772 pasase a la Sala $2^{a}$ del Consejo. Finales de 1773, principios de 1774.

39 A.H.N. Consejos. Leg. 22.605: Solicitud de Gómez Delgado para que la representación...

40 A.H.N. Consejos. Leg. 22.605: Representación del procurador Santiago Gómez... 
de balsas, tal y como lo había hecho en Gandia Antonio Vivanco ${ }^{41}$, en las que se almacenaría el agua que, esporádicamente, se perdía en el mar: «si las que dejan perder las recogieran en estanques construidos en sitios elevados, regaría mucha mayor extensión de tierra sin perjuicio de nadie. Los gastos serian a la verdad considerables, pero ventajosamente recompensados por el grande número de frutos ${ }^{42}$.

Asistida en estas razones y lejos de retirarse, la población afectada mantuvo el litigio largo tiempo, como veremos. Baste decir que el 1 de julio de 1774, poco menos de siete meses después del bando del Corregidor de Jijona, Relleu, en un nuevo intento por retrasar las obras, volvería a exponer los graves perjuicios que para la salud y economía de la baronía supondría la realización de la obra, solicitando la suspensión de la Real Provisión de 15 de enero de 1774. Sin embargo, dicha demanda no prosperó.

El 25 de febrero de 1776 se celebró una Junta extraordinaria de regantes en la que, bajo la presidencia del Corregidor de Jijona, se discutió la forma de costear los gastos del recrecimiento de la presa, construcción de una casa para guarda y otros dispendios relacionados con la empresa. Los 185 interesados que acudieron acordaron sus contribuciones en proporción del derecho de agua que poseyera cada uno, siendo esta obligación traspasada con las ventas, herencias o cesiones que pudieran efectuarse en un futuro. Tan sólo hubo un leve desacuerdo respecto a la altura del recrecimiento, estipulado en 15 palmos -3'45 metros $^{43}$ - , y que 18 de los presentes quisieron reducir, sin éxito, hasta los 10 palmos. Enviado el correspondiente recurso al Consejo, se expidió Real Provisión el 26 de noviembre de ese mismo año, aprobándose todo lo acordado en la referida Junta.

\section{Una concordia, que no fue tal}

A pesar de la resolución del Consejo y de la elaboración del proyecto de recrecimiento de la pared y su coste, la inminencia de la construcción de la obra no se produjo y, cinco años después de la solicitud, los problemas con Relleu se mantuvieron. Puede deducirse este hecho de la concordia — claramente favorable a los intereses de la baronía- que Villajoyosa se vio obligada a firmar con el pueblo vecino, tratando de evitar así un nuevo retraso en la necesaria obra.

«y cuando en este estado discurría fundamentalmente aquel común de vecinos, no hallar el menor estorbo para ver fenecida tan útil obra, después de más de un siglo que hace que se le permitió construir; ha podido la emulación y fines particulares de los vecinos de Relleu (protegidos por el poderoso influjo del Procurador General ${ }^{44}$ del Conde de Puñonrostro, Dueño directo de su término) intimidar de tal forma a los de Villajoyosa, voceando tener hechos recursos sobre el asunto a esta superioridad, que por no verse inculcados en ellos, ni sus huertas en el estado de aridez en que las constituía la falta de su preciso riego, han venido a concordarse» ${ }^{45}$

41 En efecto, la empresa de Antonio Vivanco, que había convertido en regadío sus haciendas de secano mediante la construcción de un embalse de 3 hanegadas y 14.5 palmos de profundidad que aprovechaba las aguas invernales que el río Vernisa vertía al mar, despertó la admiración en Cavanilles a su paso por Gandia, llegando a considerar que «debieran otros acaudalados imitar un ejemplo tan útil, el más propio para aumentar sus riquezas y las del Estado», en CAVANILLES, A. J. (1797): Observaciones... pág. 146. Tomo II.

42 CAVANILLES, A. J. (1797): Observaciones... pp. 243-244. Tomo II.

43 El palmo valenciano equivale a cerca de $23 \mathrm{~cm}$.

44 Desde el 12 de marzo de 1777, Francisco Marín, Procurador de los Reales Consejos.

45 A.H.N. Consejos. Leg. 22.605: Solicitud de Santiago Gómez Delgado para que se deniegue... 
Efectivamente, el 19 de noviembre de 1777, comparecieron en Valencia José Ayela, abogado y procurador general del Conde de Puñonrostro, Antonio García de Manuel y Cayetano Aragonés, diputados y apoderados de los Ayuntamientos de Relleu y Villajoyosa respectivamente, acordando, sin la presencia de un notario y a expensas de la aprobación de los respectivos plenos municipales, levantar la pared hasta un máximo de 15 palmos con las siguientes condiciones: en primer lugar, Villajoyosa debería comprar las tierras cercanas a la demarcación previamente fijada para aquellas que podrían inundarse, así como llenarse de maleza e inutilizarse por su cercanía al agua. En el caso de que la población propietaria decidiera arrendar, vender o poner en enfiteusis dichas tierras, los vecinos de Relleu tendrían siempre prioridad. A ello añadían la posibilidad de que, en una avenida del Amadorio, se anegaran porciones de terreno superiores a las calculadas, en cuyo caso Villajoyosa se vería obligada a adquirirlas o pagar los perjuicios ocasionados a los propietarios, que gozaban de la libertad para decidir una u otra indemnización. La valoración de las tierras anegadas y dañadas sería realizada por cuatro peritos, dos por cada población. Igualmente, el Conde de Puñonrostro percibiría los derechos del tercio diezmo, censo enfitéutico y luismo que les correspondería por las mencionadas tierras.

A todo ello añadían la supresión del derecho de sisa para los vecinos de Relleu que, en caso de carestía, decidieran adquirir grano para su consumo en Villajoyosa, y se insistía de nuevo en los perjuicios que sufría Relleu por la falta de leñas y demás materias primas consumidas para la obra y fabricación de la cal. En un Pleno Municipal posterior, el Ayuntamiento de Relleu estimó, esta vez ante notario, que Villajoyosa entregaría 200 libras por este concepto, invirtiéndose tal capital «en la iluminación de las aguas y cava de la Tosca $»^{46}$. De igual forma, modificaban algunos de los puntos anteriores, requiriendo, por ejemplo, que se justipreciaran las mencionadas tierras antes de levantar los 15 palmos de pared, manteniendo la jurisdicción del Conde de Puñonrostro en la obra y lago y añadían también, caso de corromperse las aguas embalsadas bajo la certificación de médicos, la obligación de Villajoyosa de vaciar el pantano, guardándose Relleu la posibilidad de hacerlo ella misma si lo creyera conveniente y con los costes de la operación a cargo de los propietarios.

No es necesario resaltar que Villajoyosa salió claramente perjudicada con la firma del documento pero, analizado el desarrollo del pleito, no resulta desatinado pensar que se tratara de una estrategia para finalizar de forma definitiva las obras. Efectivamente, parece ser que la Concordia aquietó los ánimos de Relleu y el recrecimiento de la pared, junto con la construcción de una casa para guarda, por fin pudo iniciarse. Así, resuelto este problema, sólo faltaba reponerse de los descalabros sufridos con el acuerdo de 1777. Tres años después, Villajoyosa contraatacaba a través de Santiago Gómez Delgado aduciendo que la Concordia, además de haber sido sufragada por esta población, modificaba algunos puntos inalterables y decididos del Real Privilegio de 1653, como ocurría con lo reflejado en el apartado de la corrupción del agua y desagüe de la presa. Especialmente sangrante era lo

46 A.H.N. Consejos. Leg. 22.605: Escritura de concordia y convenio otorgada entre partes de las Villas de Relleu y Villajoyosa y el procurador General del Excmo. señor Conde de Puñonrrostro, 19 de noviembre de 1777. Hemos encontrado una referencia a la iluminación de aguas en Relleu el año 1789, realizadas por el hidráulico Antonio Ferrari y Caracciolo, pero no se especifica el lugar. Se lograron 22 reales de aumento de agua, beneficiándose las huertas de la villa y el Molino de dicho pueblo con 6 horas diarias de aumento. Pese a todo, las desavenencias con el Alcalde llevaron a Ferrari a pasar 4 días en la prisión de la villa, junto con el embargo de su mula de montar. A.H.N. Consejos. Leg. 37.165: Don Antonio Ferrari Caracciolo, matemático hidráulico en el Reino de Valencia sobre los procedimientos del Alcalde mayor de la villa de Relleu en dicho reino contra su persona de resultas de haber pasado a ella una instancia de su Ayuntamiento, del descubrimiento de las aguas de una mina en el término de la referida villa. 
referido al pago de las tierras susceptibles de ser inundadas por el agua, que Villajoyosa decía haber satisfecho como clarificaba el Real Privilegio, sin dejar de recordar que, en caso de no haber reintegrado dichas compensaciones, Relleu no estaba en el derecho de demandar nada ya que «si algún terreno aprovechan hoy, confinantes con el pantano, era absolutamente inútil en aquellos primeros tiempos, y si hoy produce alguna utilidad, deriva de las fatigas y empresas que los vecinos de Villajoyosa, han empleado en reducirle a cultura, abonándole continuamente y con no poco dispendio, con el légamo y los sedimentos que naturalmente deja el rebalso y avenidas que entran en el Pantano» ${ }^{47}$. Recordaba Gómez Delgado que en 1653 no se fijó altura alguna para la presa, que parece ser que en origen ascendía a 150 palmos - 34'50 metros-, por lo que la limitación del recrecimiento a sólo 15 palmos, debían ser considerado como un acto de generosidad.

Caso aparte era todo lo referente a la corta de leñas, necesarias año tras año para las labores de desembalse del pantano, y a lo largo del pleito encontramos una constante discusión en este sentido. Finalmente, Villajoyosa, empecinada en no pagarle a Relleu por un derecho que consideraba propio, presentó ese mismo año de 1779 el testimonio del Privilegio que dicha villa poseía para cortar leñas en los términos del antiguo señorío del Almirante Bernat de Sarrià. El documento, fechado el 8 de mayo de 1300 y confirmado posteriormente por otros soberanos, otorgaba a todos los vecinos de Villajoyosa «que por todos tiempos [...] en su término y por toda la señoría del señor Bernardo, pudieran apacentar o dar pasto en sus hierbas a los ganados, como también cortar leñas y maderas para hacer barcos, galeras y todas cualesquiera cosas para su servicio, francamente y sin pagar derecho alguno en ningún tiempo $»^{48}$. Igualmente mencionaban sendas sentencias, la primera de 1686 contra el Baile y Administrador de las Baronías de Polop, La Nucia y Xirles, y la segunda de 1693 contra el Baile de Relleu, relacionadas con la corta de leñas en dichos términos y que Villajoyosa ganó mediando dicho Privilegio ${ }^{49}$.

En definitiva, una vez presentadas estas alegaciones, sólo cabía resaltar una verdad irrefutable: mediante las Reales Provisiones del Consejo de 1774 y 1776, y sin necesidad de concordia alguna, Villajoyosa estaba en su derecho de continuar las obras sin que Relleu lo pudiera impedir. La Concordia, así pues, debía de ser anulada.

Desatado de nuevo el conflicto, el pleito se complicó en intrincados embrollos que incluyeron pérdidas de autos, inmovilizaciones de expedientes y hasta un vicio de nulidad ${ }^{50}$ que fueron paulatinamente resueltos. De tal manera que, dentro del tedioso contexto de los pleitos, lo más destacable es la esperable respuesta, ya en 1783, de Francisco Marín,

47 A.H.N. Consejos. Leg. 22.605: Solicitud de Santiago Gómez Delgado para que se deniegue...

48 A.H.N. Consejos. Leg. 22.605: Solicitud de Simeón mayor, Síndico Personero de Villajoyosa, del testimonio del privilegio para cortar leñas y maderas en los términos convecinos de Relleu, Sella, Polop, Callosa y demás, que se titulan en el dia de medida Sarriana, derivado de la Señoría del noble Don Bernardo de Ensarrià. 8 de marzo de 1779.

49 La sentencia de 1686, fue provocada por el intento de dichas baronías de perturbar el corte de maderas en su término, mandándose que en adelante no perturbasen a la villa y sus vecinos la posesión de dichos usos bajo de ciertas penas. La referida a Relleu se debió al encarcelamiento de un vecino de Villajoyosa que cortó leña en el término de la baronía. La sentencia de la Real Audiencia conllevó a su excarcelación gracias a la posesión de este Privilegio.

50 Francisco Marín, en su solicitud de 1783, señaló un defecto de forma que le restaba legitimidad a Santiago Gómez Delgado para continuar con la demanda de nulidad de la Concordia. De forma resumida, consistía en que este abogado únicamente tenía poder del Síndico Personero Don Simeón Mayor, que al haber cesado de su cargo, le restaba propiedad para continuar en el caso. Gómez Delgado adujo representar también al Ayuntamiento vilero, pero el Consejo finalmente emplazó a Villajoyosa a nombrar en el plazo de quince días un procurador para proseguir con el pleito. Finalmente Gómez Delgado recibió un poder de dicho Ayuntamiento en el plazo estimado, evitándose así el mencionado defecto de nulidad. 
representante del Conde de Puñonrostro, a la solicitud de los propietarios del pantano. En el documento, Marín solicitaba al Consejo la aprobación de la Concordia, que consideraba acorde con lo establecido en el Real Privilegio. Para ello comparaba algunos puntos de ambos documentos, como ocurre con la obligación de Villajoyosa de pagar las tierras inundables, añadiendo que, en caso de haber obtenido un supuesto beneficio con la deposición de légamos, era el precio que se cobraban por haber permitido «tal inmundicia ${ }^{51}$. Respecto al escabroso asunto de la corta de leñas, apuntaba que no era de recibo citar las sentencias descritas anteriormente y que, en referencia al Privilegio de 1300, los vecinos de Villajoyosa únicamente poseían el derecho de utilizar leña en el término de Relleu para usos ordinarios, por lo que el extraordinario y excesivo consumo necesario para la realización de las obras restaba utilidad al mencionado documento, como demostraba el Real Privilegio de 1653 en cuyo capítulo noveno se especificaba el pago a la baronía del justo valor de las leñas utilizadas. De igual forma, en el aspecto referido a la corrupción de las aguas, Marín consideraba que no se contravenía el fundamento de lo afirmado por el Real Privilegio, sino que más bien era una cuestión formal respecto a la manera de reconocer la corrupción o no de las aguas. En cuanto a la altura de la pared, fijada en 15 palmos, Marín señalaba que era el resultado de un acuerdo entre ambas partes, conscientes del perjuicio que supondría para ambas rebasar dicha altura, con el consiguiente aumento de la lámina de agua y pérdida de tierras, por las que habría que abonar cierta cantidad en metálico.

Desconocemos cual fue el veredicto del Consejo respecto a la aprobación o no de la Concordia, pero sabemos, a través de documentos notariales, de la venta al Ayuntamiento y Común de regantes de Villajoyosa de tierras próximas al pantano en 1798 y 1816.

Ratificado o no el documento de avenencia, lo cierto es que la población de Relleu siguió demostrando su disconformidad respecto a la presencia del pantano. A primeros de 1790, la reja de hierro que se dispuso en el cubo de la presa fue cortada, introduciendo así tierra, piedras, trozos de pleita y atocha con el objeto de taponarlo y evitar así la salida de las aguas, lo que hizo peligrar las cosechas de verano y hortalizas. Una vez reparado el daño, tras invertir una suma importante para ello, el 1 de febrero, a petición de Don Juan Zaragoza, Procurador General de Villajoyosa, el notario de Relleu, Vicente Pérez Cantó, levantaba testimonio de los nuevos perjuicios - esta vez considerables - sufridos por la obra del pantano y casa del guardia. El brocal del cubo había sido derruido con un instrumento agudo y cortante, mientras que sobre la reja se hallaban unos pedazos de piedra similares a los de la pared y con restos de cal; asimismo, «casi en el medio de la pared y sobre la cara de fuera se halla un hoyo como de un palmo de profundidad y palmo y tres cuartos dedos de longitud o circunferencia, y la última fila de piedra picada a la posterior de dicha pared, que mira y confina a la parte de la Sierra de Orcheta solponiente, que faltan once palmos y cuarto de longitud en poca diferencia de pared, con dos palmos de profundidad, cuyo vacío era ocupado de fila de piedra picada, las que no se hallan en el sitio, sí solo la cal de su obra» ${ }^{52}$. La casa del guardia tampoco se libró de la ira de los de Relleu: la chimenea y el pesebre destruidos, junto con la puerta, hecha astillas y convertida en cenizas, así lo atestiguaban.

Ante tales excesos, que no se adecuaban en ningún momento a las amenazas de multa del Corregidor de Jijona, y las cuantiosas pérdidas económicas que entrañaban, el Común

51 A.H.N. Consejos. Leg. 22.605: memorial de Francisco Marín, apoderado del Conde de Puñoenrostro, en defensa del documento de Concordia de 17 de noviembre de 1777.

52 A.H.N. Consejos. Leg. 22.605: Testimonio de Vicente Pérez Cantó, Notario de Relleu a petición de D. Juan Zaragoza, Procurador General de Villajoyosa, sobre los daños que ha sufrido la obra del pantano y casa de Guardia, 1 de febrero de 1790. 
de Villajoyosa decidió solicitar amparo al Consejo de Castilla en 1790. En su reclamación acusaba a las autoridades de Relleu que, «en vez de contener a los vecinos, los animan públicamente a incurrir en los citados crímenes y ocasionar a los de Villajoyosa los perjuicios y menoscabos que dejan conocerse; llegando al extremo de jactarse por las plazas y calles de Relleu y otros parajes, que destruirán el pantano, aunque sea con un barril de pólvora $»^{53}$. Consideraban igualmente que las proximidades del pantano eran habitadas por $«$ gentes ociosas» ${ }^{54}$, que desde los orígenes de la obra, amenazaban constantemente a los trabajadores sin que las autoridades de Relleu hicieran nada por impedirlo: «les presentan frecuentemente armas aún de las prohibidas ${ }^{55}$, con el peligro de que se produjeran enfrentamientos entre vecinos de ambas poblaciones. Solicitaban, en definitiva, que se comisionara a las autoridades de la Baronía de Finestrat para contener los excesos de Relleu, castigar a los delincuentes y resarcir a Villajoyosa de los daños ocasionados.

El Consejo, en respuesta de 7 de diciembre de 1790, alegó su incompetencia en un asunto exclusivo de la Real Audiencia, «a quien corresponde castigar semejantes excesos, celar sobre la tranquilidad de los pueblos de su departamento y tomar las providencias oportunas para que sus moradores no experimenten la vejación y molestias que se refieren» ${ }^{56}$.

\section{Más problemas para Villajoyosa}

Pero no era únicamente el dilatado pleito con Relleu lo que inquietaba al ayuntamiento vilero; a los costosos gastos de las obras, computados en 17.000 pesos en la subasta de obras de 1653, 7.000 pesos en los diferentes reparos realizados durante el siglo XVIII, junto con los gastos de conservación — que ascendían a 200 pesos- se unían las cuantías desembolsadas en trámites burocráticos y judiciales, mermando todo ello las arcas municipales. Esta situación provocó, en 1779, que el Común de la villa —que había sufragado en su totalidad los mentados costes - se lamentara de la escasa ayuda del párroco y del cabildo eclesiástico —únicamente 100 pesos donados por el primero- para el sustento de una obra de la que habían obtenido pingües beneficios. Demostraba esto último el aumento que por los diezmos de las tierras de huerta cobraba el Cabildo catedralicio - de 100 pesos antes de la construcción del pantano a los 1.000 de aquel entonces-y de las primicias para el párroco — de 200 a 2.000 pesos — por lo que, considerando el lógico incremento de beneficios que reportaba el aumento de la pared, el Común solicitaba el poder para embargar a los arrendadores de los diezmos «aquella parte de ellos que deriven del aumento del pantano» ${ }^{57}$.

A los problemas con la Iglesia, y a la muerte de Santiago Gómez Delgado en 1785, se unió un litigio de importantes consecuencias entre el Ayuntamiento de la villa y el Intendente del Reino de Valencia por la administración fraudulenta de las aguas de riego.

No era la primera vez que se señalaban problemas en este sentido. A los continuos hurtos de agua, quejas, acusaciones entre regantes y conflictos con los molinos por reten-

53 A.H.N. Consejos. Leg. 22.605: Santiago Estacho, apoderado del Ayuntamiento de Villajoyosa, por el recurso de protección y amparo al Consejo, ante los ataques al pantano. Año 1790.

54 A.H.N. Consejos. Leg. 22.605: Santiago Estacho, apoderado del Ayuntamiento de Villajoyosa...

55 A.H.N. Consejos. Leg. 22.605: Santiago Estacho, apoderado del Ayuntamiento de Villajoyosa...

56 A.H.N. Consejos. Leg. 22.605: Respuesta del Consejo a la solicitud de Santiago Estacho, 7 de diciembre de 1790 .

57 A.H.N. Consejos. Leg. 22.605: Solicitud de Santiago Gómez Delgado para que se deniegue... 
ciones de aguas ${ }^{58}$ a lo largo de todo el siglo, se sumaban contrariedades en el repartimiento del agua, con mandadores que, desviándolo a otras heredades, no hacían llegar el riego a sus propietarios ${ }^{59}$.

Tal suma de infracciones fue la causa definitiva para que el Intendente valenciano, Pedro Francisco de Pueyo, en 1783, «apartara al Ayuntamiento de la administración y régimen de las aguas de los riegos de aquella villa ${ }^{60} »$, convirtiéndose así en el único administrador de las mismas, ante las denuncias de seis regantes de Villajoyosa por el perjuicio que causaban los gobernantes de esta villa en la gestión de las aguas, «también por el conocido interés que en ellas tienen las rentas municipales, por la de cien y más libras que anualmente producen a las mismas (a través del impuesto de la Peita), por el de las horas de aguas propias que disfrutan (el propio ayuntamiento)» ${ }^{61}$.

Ese mismo año, y a través de su comisionado Simeón Mayor, se apoderó de los libros que el Ayuntamiento poseía para realizar dichos repartos, con el fin de determinar el porcentaje de agua que pertenecía a cada vecino así como también la forma de disponer de los fondos procedentes de la administración de las aguas para efectuar obras en acequias y azudes. Finalmente, el comisionado, bajo la supervisión del Intendente, estableció nuevos libros padrones y ordenanzas de riego. Ante lo que consideraba un abuso, Villajoyosa acudió a la Real Audiencia, iniciándose otro costoso pleito, que obligó a reunir al común de regantes el 2 de febrero de 1785, con el fin de estudiar la forma de sufragar el litigio ${ }^{62}$. Un año antes, la Audiencia previno que la Intendencia devolviera a Villajoyosa los mentados libros y que se inhibiera de un asunto que era competencia de su tribunal. A todo ello se negó el Intendente, aduciendo que el asunto correspondía a los Propios de dicha villa y, por tanto, a su autoridad.

Principiado así un conflicto de competencias, por otra parte habitual, entre la Real Audiencia y el Intendente, se elevó instancia al Consejo. La Real Cámara consideró, a finales de 1785, que la administración de las aguas y el pago de los regantes del derecho de Peita no era en beneficio de los Propios de la villa, toda vez que se invertía en la composición de presas, limpieza de acequias y todo lo relativo a la conservación del regadío. Por tanto, ya que no poseían los Propios ingresos procedentes de la gestión de las aguas, la intervención del Intendente únicamente podría justificarse para solucionar cualquier abuso que produjese la administración de las aguas, lo cual resultaba ser asunto de la jurisdicción ordinaria y, por tanto, de la Audiencia. Los libros de reparto y ordenanzas del riego formalizados por Simeón Mayor, quedaban igualmente inhabilitados y se exhortaba a la Audiencia a que corrigiera los desarreglos que se hubieran cometido en el reparto y distribución de las aguas, estableciendo así los libros y ordenanzas que mejor convinieran.

58 Especialmente significativa es la queja elevada al pleno del Ayuntamiento de 17 de marzo de 1721, en la que se reflejaba el clamor popular «por los muchos abusos que se hacen, así como hurtarse las aguas regantes unos vecinos a otros con diferentes pretextos y cautelas, como en la detención de las aguas que hacen los molineros, rebalsando el agua con las cupadas que hacen...», en A.M.V., Libro de Deliberaciones, Acta del 17 de marzo de 1721.

59 Tal suceso ocurrió con el mandador Francisco Esquerdo, que no habiendo «cumplido en mandar el agua a los dueños de ella, si antes bien se ha experimentado haberla mandado a muchos regantes, que no la tienen, por cuyos motivos se ha visto claramente en las dos tandas próximas pasadas haberle faltado mucho agua», fue cesado de su cargo en el pleno del Ayuntamiento de 24 de junio de 1746. A.M.V. Libro de Deliberaciones.

60 A.H.N. Consejos. Leg. 22.605: Poder del Ayuntamiento de Villajoyosa a Don Vicente Palos para que represente los intereses del mismo ante la Audiencia.

61 A.H.N. Consejos. Leg. 37.149: Memorial de Pedro Francisco de Pueyo a Campomanes. 29 de marzo de 1785.

62 Finalmente se concluyó, con la venia del Consejo de Castilla, que cada regante aportaría su contribución en función del agua que poseyera. 


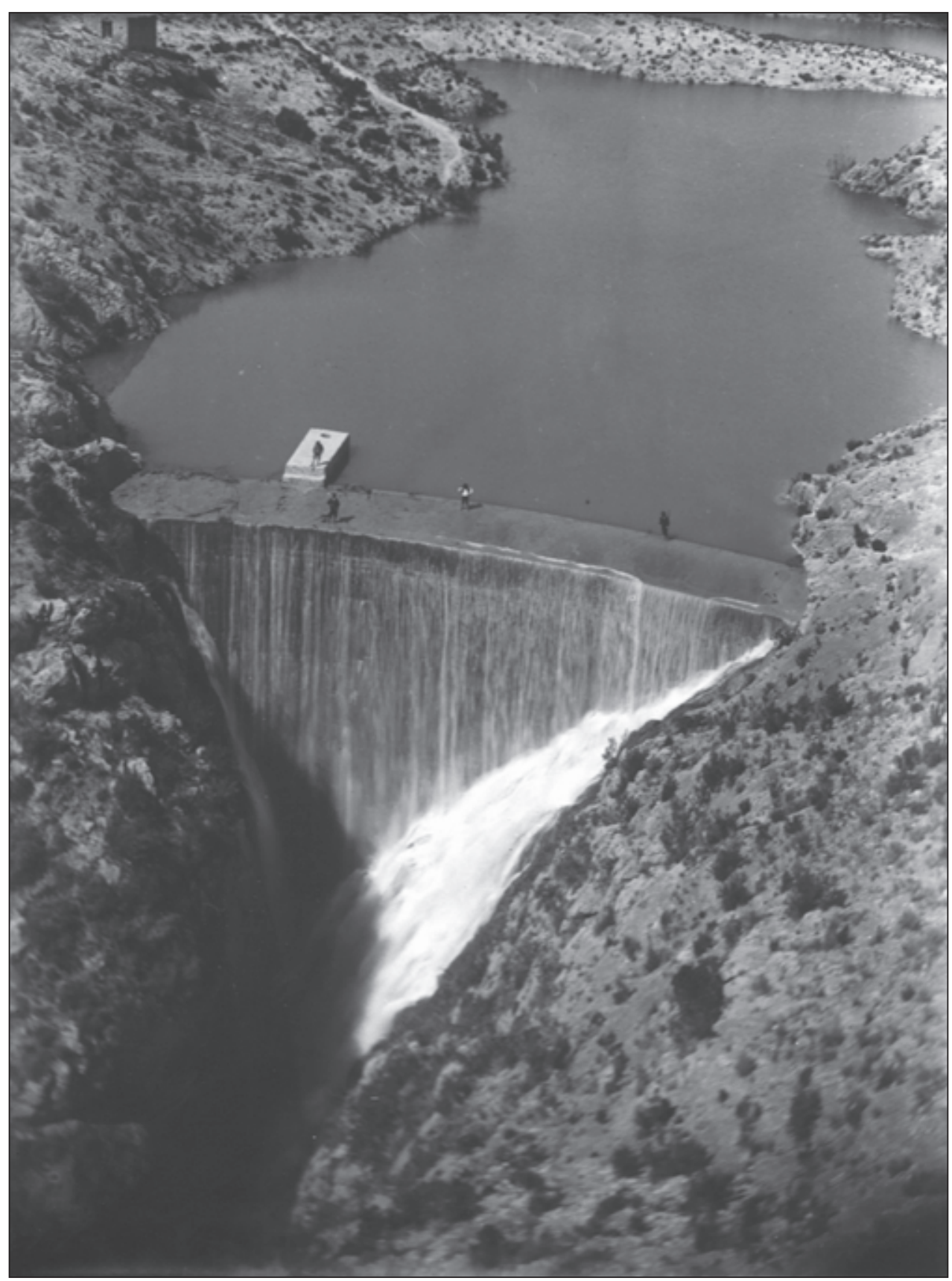

Fото 2. El pantano de Relleu en la última década del siglo XIX, cuando todavía era una pieza fundamental en el regadío de la huerta vilera. Obsérvese el vertido de excedentes por coronación y la presencia de la casa de guardia en la parte superior izquierda de la imagen. Placa fotográfica de Leopoldo Soler, Archivo Municipal de Villajoyosa. 
En 1810 se intentó sin éxito la redacción un nuevo reglamento, por lo que el desbarajuste creado por la intervención del Intendente no encontró visos de solución hasta 1834, cuando finalmente se formalizó un nuevo «Reglamento de las Aguas de Villajoyosa», cuya principal novedad residía en la reorganización del sistema de repartimiento del agua, comenzándose a regar por días y horas. A su vez, las autoridades provinciales, en la línea ideológica del reformismo liberal, recortaron la implicación de los municipios en la gestión, privilegiando así la figura de los grandes propietarios que controlaban las juntas (Ferrer y Sanchis, 2001). La gestión comunal del agua, debilitada por los conflictos internos, dio paso a una nueva figura en la ordenación del riego: en 1889, y bajo los auspicios de la Ley de Aguas de 13 de junio de 1879, los propietarios y usuarios del riego mayor de esta población se constituyeron en Comunidad de regantes, redactando unas nuevas ordenanzas y reglamento que fueron aprobados en 1907. A partir de ese momento, la gestión del agua se independizó definitivamente del Ayuntamiento y el alcalde ordinario, que hasta entonces presidía una Junta compuesta de seis patrimonialistas, cedió la dirección al presidente de la Comunidad y al del Sindicato, en una época de grandes proyectos - recordemos la construcción de l'assut Gran y el dels Plans- en la que el pantano de Relleu seguía manteniendo una posición determinante.

\section{A modo de conclusión}

En 1879, último año de una feroz sequía que afectó a gran parte del país, se llevó a cabo un sencillo proyecto de recrecimiento con poco más de 5 metros de altura y 4 de grosor que consiguió levantar la presa hasta los 31,85 metros. No obstante, esta obra ya padecía importantes insuficiencias en su funcionalidad: la progresiva colmatación del vaso debió alcanzar por aquella época niveles preocupantes, lo que unido a su reducida capacidad, fueron restándole utilidad. Las soluciones a estos problemas, sin embargo, fueron buscadas con tesón por los vileros, conscientes de que la única forma de luchar contra los lodos en una construcción con un deficiente sistema de limpia era la de recrecer la pared. A comienzos del siglo veinte, Figueras Pacheco citaba un proyecto para elevar la pared hasta los 44 metros, incrementando así la capacidad del pantano en 4,4 $\mathrm{hm}^{3}$. En efecto, un Real Decreto de 25 de abril de 1902 suponía el comienzo de una serie de infructuosos planes de recrecimiento, encabezados por Fernando Trénor en 1903, Próspero Lafarga, Felipe Rivero en 1909, junto con otros dos de 1933 y 1935 que, como el resto, no se llevaron a cabo.

Fueron los últimos intentos de revitalizar el rendimiento de un proyecto que, paulatinamente, fue cayendo en el abandono a partir de los años treinta, momento en el que empezó a fraguarse la construcción de la presa del Amadorio, iniciada finalmente en 1947. Ese mismo año se aprobó un nuevo reglamento de riego por el cual se adscribía la propiedad del agua a la de la tierra, inaugurándose así una nueva época para la huerta de Villajoyosa, en la que el pantano de Relleu quedó relegado a lo que es hoy: un ejemplo admirable de la técnica que lo levantó, del trabajo humano realizado en condiciones extremas, de la tenacidad de un pueblo —el mediterráneo, si se quiere- en su sempiterna lucha contra la falta de agua.

\section{Bibliografía}

ALBEROLA ROMA, A. (1988): «La lucha del hombre contra el medio en el Mediterráneo occidental y su incidencia en las tierras valencianas durante la Edad Moderna» en Canelobre $\mathrm{n}^{\circ}$ 12-13, Ed. I. C. «Juan Gil-Albert», Diputación Provincial de Alicante, pp. 46-54. 
- (1994): El pantano de Tibi y el sistema de riegos en la huerta de Alicante. Ed. I. C. «Juan GilAlbert», Diputación Provincial de Alicante y C.A.M. pp. 194.

- (1999): Catástrofe, economía y acción política en la Valencia del siglo XVIII Ed. Institució Alfons el Magnànim. Valencia, pp. 330.

ALBEROLA, A.; BERNABÉ, D. (1999): «Tercianas y calenturas en tierras meridionales valencianas: una aproximación a la realidad médica y social del siglo XVIII» en Revista de Historia Moderna. Anales de la Universidad de Alicante, $n^{\circ}$ 17. Alicante, pp. 95-112.

ARTOLA GALLEGO, M. (1978): Antiguo régimen y revolución liberal. Ed. Ariel. Madrid, 318 pp.

BRAUDEL, F. (1976): El Mediterráneo y el mundo mediterráneo en la época de Felipe II. Vol. I, ed. Fondo de Cultura Económica, Madrid, 858 pp.

CASTAÑEDA Y ALCOVER, V. (1919): Relaciones Geográficas, Topográficas e Históricas del Reino de Valencia de Tomás López. S (XVIII). Ed. facsímil de la Generalitat Valenciana, 1998. Tomos II. Pp. 200.

CAVANILLES, A. J. (1797): Observaciones sobre la Historia Natural, Geografía, Agricultura, Población y Frutos del Reyno de Valencia. Imprenta Real de Madrid. Ed. facsímil, Valencia, 1987, tomo II, $339 \mathrm{pp}$.

FERRI RAMÍREZ, M.; SANCHIS IBOR, C. (2001): «De Comuners a regants. Comunitat, territori i conflicte a les hortes valencianes» en Afers $\mathrm{n}^{\circ}$ 40, Ed. Afers y C.E.I.C. Alfons el Vell, Catarroja, pp. 641-654.

FIGUERAS PACHECO, F. (1913-1925): «Provincia de Alicante» en CARRERAS Y CANDI, F.: Geografía General del Reino de Valencia, Vol. V. Ed. Alberto Martín. Barcelona, pp. 2010.

GIL OLCINA, A. (1972): «Embalses españoles de los siglos XVIII y XIX para riego» en Estudios Geográficos, no 129, Universidad Autónoma de Madrid, pp. 557-596.

- (1993): La propiedad de aguas perennes en el Sureste ibérico. Ed. Universidad de Alicante, 191 pp.

- (1995): «Evolución histórica del problema del agua en los regadíos deficitarios alicantinos», en ALBEROLA ROMA, A. (ed.): Cuatro Siglos de técnica hidráulica en tierras alicantinas. Ed. I. C. «Juan Gil-Albert», Diputación Provincial de Alicante, pp. 13-30.

GÓMEZ NAVARRO, J. y JUAN-ARACIL, J. (1952): Saltos de agua y presas de embalse, Madrid. Cit. en FERNÁNDEZ ORDÓÑEZ, J.A. (Dir.): Catálogo de noventa Presas y Azudes españoles anteriores a 1900. Ed. Comisión de Estudios Históricos de Obras Públicas y Urbanismo. Madrid, 1984, $511 \mathrm{pp}$.

LÓPEZ GÓMEZ, A. (1971): «Embalses de los siglos XVI y XVII en Levante», en Estudios Geográficos, ${ }^{\circ} 125$ Ed. Universidad Autónoma de Madrid, pp. 617-656.

- (1987): Els embassaments valencians antics. Ed. C.O.P.U.T, Generalitat Valenciana. València, pp. 72.

- (1988): Antiguos riegos marginales de Aranjuez. («Mares», azudes, minas y canales). Discurso de ingreso en la Real Academia de la Historia. Ed. R.A.H., Madrid, 74 pp.

- (1995): «Las presas españolas del siglo XVI. Antecedentes e innovaciones revolucionarias» en ALBEROLA ROMA, A. (ed.): Cuatro Siglos de técnica hidráulica en tierras alicantinas. Ed. I. C. «Juan Gil-Albert», Diputación Provincial ded Alicante, pp. 89-116.

MADOZ, P. (1845-1850): Diccionario Geográfico-Estadístico-Histórico de Alicante, Castellón y Valencia. Edición de la Institució «Alfons el Magnànim». Diputació Provincial de Valencia, 1982. 2 Tomos.

NAVARRO VERA, J. R. (1995): «De Tibi a Isber. Cuatrocientos años de presas históricas alicantinas» en ALBEROLA ROMA, A. (ed.): Cuatro Siglos de técnica hidráulica en tierras alicantinas. Ed. I. C. «Juan Gil-Albert», Diputación Provincial de Alicante, pp. 159-172.

LORENZO PARDO, M. (1933): Plan Nacional de Obras Hidráulicas. Ed. M.O.P.T.M.A. Tomo II, Madrid, 1993.

QUEREDA SALA, J. J. (1978): Comarca de La Marina (Alicante). Estudio de Geografía Regional. Ed. Excma. Diputación Provincial de Alicante. Pp. 431.

RUIZ TORRES, P. (1989): «La agricultura valenciana en el siglo XVIII», en Estructuras agrarias y reformismo ilustrado en la España del siglo XVIII, Madrid, pp. 99-132. 